\title{
NATIVE WATERSCAPES IN THE NORTHERN BORDERLANDS: RESTORING TRADITIONAL ENVIRONMENTAL KNOWLEDGE IN LINDA HOGAN'S SOLAR STORMS
}

\author{
ANNA M. BRÍGIDO-CORACHÁN \\ University of Valencia \\ Anna.M.Brigido@uv.es
}

Received 4 July 2018

Accepted 17 January 2019

\section{KEYWORDS}

Waterscape; Linda Hogan; Solar Storms; traditional environmental knowledge; Native American literature; political geography; water rights

\section{PALABRAS CLAVE}

Entornos acuáticos; Linda Hogan; Solar Storms; conocimiento ecológico tradicional; literatura nativo-americana; geografia política; derecho del agua

\section{ABSTRACT}

In her novel Solar Storms (1995) Chickasaw novelist and poet Linda Hogan foresees what political geographers today refer to as waterscapes, that is, water-based environments where a multiplicity of human and other-than-human forces interact with each other producing diverse forms of signification. This essay examines Indigenous experiences of water, geography, and social activism as they intersect in Hogan's waterscape narrative. I ground my analysis of this visionary novel in recent geographical studies that look at waterscapes from the perspective of cultural politics and which criticize rationalist conceptions of water that reduce it to the sole function of human commodity. Challenging such a reductionist view, Western and non-Western political geographers have begun to take into account traditional environmental knowledge (TEK), local ecologies, and historically rooted, alternative social practices to argue that water environments produce meaning through the ways human and other-than-human beings experience them, and this includes beings such as the earth or water. In this article I contend that such a view is the epistemological backbone sustaining Hogan's Solar Storms. While the potential swirling action of water as a form of environmental and spiritual power is strongly highlighted, I also 
consider how alternative cartographical practices and stories may challenge the boundaries of colonial dominance and propose ways in which Hogan's waterscape may contribute to contemporary geographical and political debates concerning home, territory, sovereignty, and sustainability in the Americas.

\section{RESUMEN}

En su novela Solar Storms (1995), la novelista y poeta Chickasaw Linda Hogan anticipa el concepto de waterscape, un entorno natural acuático en el cual (tal y como se empieza a reconocer en el campo de la geografia política contemporánea) una multiplicidad de agentes humanos y no-humanos interactúa entre sí produciendo diferentes niveles de sentido. Este artículo considera el modo en que las comunidades indígenas entienden el agua, la geografia y el activismo social tomando como punto de partida los waterscapes descritos por Linda Hogan. Mi análisis está fundamentado en estudios geográficos recientes, los cuales examinan estos entornos acuáticos atendiendo a las nuevas políticas geoculturales, a la par que critican conceptualizaciones racionales occidentales que reducen el agua a la mera función de mercancía o recurso. Cuestionando esta perspectiva reduccionista, numerosos geógrafos politicos, occidentales y no occidentales, empiezan a reconocer el valor de la sabiduría ecológica tradicional de las comunidades indigenas, las prácticas ecológicas locales, así como una serie de prácticas geosociales alternativas que tienen también un fuerte arraigo histórico. Este grupo creciente de geógrafos alega que los entornos acuáticos cobran también significado a través de las múltiples experiencias que los seres humanos y no humanos tenemos de los mismos y esto incluye a seres naturales como la tierra o el agua. En este artículo defiendo que esta perspectiva orgánica y multivocal constituye el eje fundamental que sustenta la novela de Hogan. Paralelamente, demuestro cómo las historias y prácticas cartográficas alternativas presentadas en la novela, junto a la acción arremolinadora del agua como fuerza medioambiental y espiritual, cuestionan los limites del orden colonial dominante proponiendo maneras de intervención en los debates geopolíticos contemporáneos sobre hogar, territorio, soberania y sostenibilidad en la América indígena.

"water would do what it wanted and in its own way" (Linda Hogan, Solar Storms 224) 


\section{INTRODUCTION}

In her novel Solar Storms, published in 1995, Chickasaw novelist and poet Linda Hogan anticipates and effectively describes what political geographers today refer to as waterscapes-dynamic water-based environments where a multiplicity of human and other-than-human forces interact with each other producing diverse forms of experience and signification. This essay aims to examine Indigenous experiences of water, geography, and social activism as they intersect in Hogan's waterscape narrative. I ground my analysis of the novel in recent geographical studies that look at waterscapes from the perspective of cultural politics and which criticize rationalist conceptions of water that reduce it to the sole function of human commodity. Challenging such a reductionist view, many Western and non-Western political geographers have begun to take into account traditional environmental knowledge (TEK), local ecologies, and historically rooted, alternative social practices to argue that water environments are "experientially meaningful" (Orlove and Caton's term 408). ${ }^{1}$ This organic, multivocal view of waterscapes-one that acknowledges and respects a wide variety of human and other-than human experiences and practices-is a central component of the traditional environmental knowledge held by many Indigenous communities of the Americas. In this article I contend that such a view is the epistemological backbone sustaining Hogan's Solar Storms-a visionary novel that restores and activates Indigenous knowledge for generations to come.

The theoretical framework used to highlight Hogan's spiritual beliefs and ecological pursuits draws mainly from the works of two Native American geographers: Glen Coulthard (Yellow Knives Dene) and Deborah McGregor (Anishinaabe). Other central ideas and concepts are taken from Hogan's own depiction of traditional Indigenous knowledge in North America, and from the work of contemporary postcolonial geographers and sociologists such as Amitangshu Acharya or Amita Baviskar. Moreover, recent ecocritical studies tackling interspecies dialogues (Plumwood 2002; Flys 2011) and land ethics (Schweniger 2010) in traditional Native American cultures have also informed this article.

${ }^{1}$ See Baviskar (2007); Orlove and Caton (2010); Acharya (2015). 
Before I appraise the relevance of Solar Storms as a pioneering TEK-grounded novel, I briefly review the historical genealogy and growing importance of waterscapes in $21^{\text {st }}$ century political geography. I also address the role and function of water as a living entity in Native American cultures and epistemologies and discuss Indigenous waterscapes as multilayered, multi-experiential environments that are based on interdependence and respect. The second part of this essay examines Linda Hogan's novel and identifies creative ways in which Hogan's literary waterscape anticipates and may therefore have contributed key ideas to scholarly debates concerning sustainable water environments in North America. 2 I specifically argue that Hogan's countercartographical practices, together with her characters' experiential conception and communicative relationship with water, challenge the boundaries of colonial environmental dominance while the potential swirling action of water functions as form of spiritual power triggering socio-political mobilization, restoration, and resurgence at the personal and community level.

\section{WATERSCAPES: TOWARDS CULTURAL AND ENVIRONMENTAL SUSTAINABILITY}

Waterscape as an artistic term has been in use since the 1850s and has traditionally referred to pictorial renderings of a landscape containing a body of water. Waterscape as a geographical concept gained popularity among political geographers in 1999, when Erik Swyngedouw introduced it to describe the cultural context of water management in Spain in the early $20^{\text {th }}$ century. Since then, an explosion of scholarly studies on waterscapes around the world has taken place, all of which highlight the ideological, cultural and experiential dimensions of waterscapes in a variety of geographical and historical contexts (Orlove and Caton 468). Brought together

\footnotetext{
${ }^{2}$ Although water as an animated, communicative being is often depicted in Hogan's fiction and non-fiction works, Solar Storms offers the most complex and thorough rendering of water within a historical waterscape-one in which many human and other-than-human beings have interacted for centuries. For complementary studies of water's subjecthood in Hogan's other novels see also Cook (2003), Flys (2011), and Smith and Holland (2016). Smith and Holland specifically root their analysis of Hogan's work in Chickasaw water histories and modes of spirituality, which permeate Hogan's ideas even when the novels explore non-Chickasaw Native cultures.
} 
under the overarching field of IWRM (Integrated Water Resource Management), geographers, anthropologists, and other social scientists claim that any study of water as a resource must go beyond traditional agricultural or energetic principles and take into account this historical, cultural, spiritual, and experiential dimension. ${ }^{3}$ As Amitangshu Acharya puts it: waterscapes have to be "understood as a complex assemblage of emotions, worldviews, practices and processes, as well as symbolic and material politics" (381). Approaching water from the perspective of cultural politics necessarily entails taking into account issues of sustainability, cultural symbolism, spirituality, social inequality and justice-that is, considering water within a discourse that challenges environmental determinism (Baviskar 2003: 50-52; Acharya 375). ${ }^{4}$ Consequently, the symbolic, cultural, and historical dimensions of water and its multivocality (Kamash 225) are gaining center stage in contemporary discussions of water management.

For Native American communities, water is more than an inert and valuable natural resource that has been historically conducted and controlled to suit human needs. Water is a living entity with a central role in Indigenous practices, creation stories, spirituality, and cultural identity throughout the Americas. The creation story of the Anishinaabe, the Iroquois and of many other northern tribes depicts a great flood and features a variety of water animals whose central role and collaborative actions are key to the emergence of North America or Turtle Island. ${ }^{5}$ The Paiutes tell the story of Ocean Woman, the first living being, who fell into a world that was made of water and with her skin and movements shaped the relief of the earth (Trafzer 2015). The Paiutes consider water a source of healing and of power or puha, and the connection between water and puha is present in many of their traditional stories, contemporary ceremonial practices, and also in place-names that function as sites of historical memory (Trafzer 2016; Bauer Jr. 2016). In New Mexico, Pueblo communities regard "natural springs and

\footnotetext{
${ }^{3}$ IWRM is the "hegemonic paradigm for discussing, legitimizing, and implementing policies regarding the management of the world's water resources" towards sustainable development (Orlove and Caton 408).

${ }^{4}$ Environmental determinism can be defined as the purely rational consideration of the natural world as a commodity.

${ }^{5}$ See for example the Anishinaabe creation narrative in Basil Johnston's classic volume of Ojibway tales.
} 
fresh-water lakes" as thresholds into the four worlds laying beneath our world-strategic openings that allow them to communicate with their ancestors (Silko 20). For the Mayas in Central America, water has a sacred nature and is often associated with divination. On the other hand, both surface water and groundwater are believed to feed the lifeblood of Nookomis oki, the Grandmother Earth of Sokaogon communities in Wisconsin (Reynolds 2003: 13). ${ }^{6}$ For the Chickasaw and for other Southern tribes that were forcibly moved to Oklahoma in the mid-19th century, water also had a central role in the configuration of their storied worlds; it was not a mere "commodity necessary for survival; it was tied to Chickasaws' spiritual lives as well" (Smith and Holland 58).

So, while white settlers in America have imposed human dominance over all other living and material things, traditional Native American knowledge posits that all elements of the universe must respect one another as they are all "alive and interconnected" (Reynolds 144). As Anishinaabe geographer Deborah McGregor points out, traditional environmental knowledge is "fundamentally about relationships. It considers relationships not only among people, but rather among all our relations, including all living things, the spirit world, our ancestors and those yet to come" (78). For many Native American tribes water is precious and has human-like abilities; it has a language, agency, and interests that must be acknowledged and respected. Water can thus be regarded as an "other-than-human person" (Hallowel's term 1960) in Native American philosophies and cultural practices, which assume that humans have to engage water (and all other animate beings) in a context of "reciprocal relationality" (Barrett 2009), responsibility, and care (McGregor 2013). For Yellow Knives Dene scholar Glen Coulthard, Native American relations to the land are traditionally grounded on the "principles of reciprocity, non-exploitation, and respectful coexistence" (Coulthard 2014: 12)-a radical form of relationality that he calls "place-based solidarity" (2016).

Since the 1970s, Native American artists, writers, and activists have in fact risen to defend their territories and to claim

\footnotetext{
${ }^{6}$ See also "Material Nature, Visual Sovereignty, and Water Rights: Unpacking the Standing Rock Movement" (Brigido-Corachán 2017), where these contexts and other related issues regarding water management, sustainability, and spirituality are considered and further developed in connection with the \#noDAPL Movement.
} 
sovereignty over the natural environment they coexist withenvironments wherein communities of people live in such reciprocal relation to the land, its living creatures and its bodies of water (Brígido-Corachán 2017). These groups demand new environmental practices and legislation that recognize and respect water's own right to exist in a place. These legal and ontological changes have recently been accomplished by the Maori in New Zealand, where the Whanganui River has achieved human legal status, or the Ganges and Yamuna rivers in India, which have also been recently declared "living human entities". ${ }^{7}$ Since the turn of the century, traditional environmental knowledge has also been featured in United Nations' discussions and in other international forums on biodiversity, environmental justice, and sustainability.

\section{NATIVE WATERSCAPES IN LINDA HOGAN'S SOLAR STORMS}

As many scholars have pointed out (Dreese 1999; Tarter 2000; Hans 2003; Arnold 2004, among others) and any reader can immediately notice, Linda Hogan's novel, Solar Storms, is heavily grounded on water tropes that emphasize water qualities such as dynamism, contact, and transformation. In the novel water is often described as a mirror, a window, a catalyst, a healing fixture, a memory triggerer, and an empowering force. Water at Adam's Rib, the town where the story begins, is "iron-rich" and makes everything "smell like blood" (Solar Storms 33, SS henceforth). Water junctures in the novel become sites "where fatigue yielded to comfort, where a woman renewed herself" (SS 44) and the portrayal of water as having animated, human-like features such as a language, communicative

\footnotetext{
7 The Ganges River is regarded as a sacred entity by over 1 billion Indians and, since March 2017, it has three legal custodians overseeing its protection so that polluting or damaging the river has legal consequences comparable to those affecting harmed human bodies. In New Zealand, the Maori also consider the Whanganui River their ancestor. This establishes a disheartening contrast with the special status of corporations and trust funds in the United States which, unlike water, animals, and natural environments, do have human legal status. On the environmental and legal breakthrough regarding the Ganges and Whanganui Rivers see Safi and BBC News' articles (2017).
} 
abilities, and "her own needs ...and desires" (SS 279) is persistent throughout the whole novel. ${ }^{8}$

Set in the area of the Boundary Waters between Minnesota and Ontario (an intricate network of shifting waterways, lakes, rivers and minor streams that, still to this day, can often be navigated only by canoe), Hogan's novel depicts the northern borderlands as a very fluid frontier that is easy to transgress by those familiar with its complex landscapes. Hogan's water tropes are often articulated around two cartographical concepts: surface and depth. In the border between Canada and the United States, water challenges the superficial arrangement of Western maps-colonial maps which have traditionally obscured the multivocal depth of historical experiences in Native territories. The novel also identifies ancient Indigenous waterways and pictographs, hidden deep under water, which reveal an ongoing Native presence and intimate engagement with the waterscapes of the Americas. In the lake by Adam's Rib, The Hungry Mouth of Water (a mysterious spot that never freezes and which has swallowed a variety of creatures and objects) becomes the repository of many overlapping histories. The Hungry Mouth functions as an archive of frozen historical experiences including those of a beluga, the carcasses of hunters, a colonial shipwreck, or the skeleton of the great elk (SS 63). When crossing by the Mouth, one of the Native characters, Husk, feeds the sacred water some tobacco, cornmeal, and bread to appease its hunger, to honor the multilayered memories that have been preserved for centuries as if shielded in amber or peat.

Amid this complex historical waterscape, Hogan's novel features a group of four native women, centenary great-greatgrandmother Dora-Rouge, great grandmother Agnes, surrogate grandmother Bush, and granddaughter Angel, who is the narrator of the story. Dealing with identity loss, trauma, and environmental

8 The dualistic function of water as a healing device with "restorative power" (restoring cultural and spiritual values) but also as a trope that conjures environmental destruction and injustice in the novel has been pointed out by several authors such as Dreese (1999) or Arnold (2004). Barbara J. Cook also refers to earth and water as being animated and having anthropomorphic qualities in Hogan's fiction (2003) while Hogan's continuous literary engagement with water spirituality, sustainability, tribal sovereignty, and social justice is thoroughly explored by Smith and Holland (2016) in direct connection with ongoing Chickasaw water claims in Oklahoma, Hogan's place of origin. 
disaster among other things, these women decide to travel the dense network of waterways from the Boundary Waters area in Minnesota to Canada in order to stop the construction of a dam that is going to flood their ancestral lands down south. It is 1972 and, as the American Indian Movement is gaining visibility, these four women are inspired to take action.

Although the tribe of the Fat-Eaters they belong to is fictional, Hogan's literary community of abandoned women and men feeds from Anishinaabe, Cree, and Inuit traditions and histories. Moreover, as many critics have pointed out, the events depicted in this novel are directly based on the struggles that befell Cree and Inuit communities in protests against the construction of the HydroQuebec complex of dams in James Bay. In the early 1970s, the disproportionate erection of over 200 dams flooded forty-five hundred square miles of land around massive James Bay, mostly around the La Grande and Eastmain Rivers, provoking the re-routing of several rivers and the dramatic destruction of wildlife and the landscape. This project also forced several Cree and Inuit communities to relocate after their hunting and fishing grounds were flooded-an environmental catastrophe which was aggravated when mercury poisoning (released from the bedrock) tainted the fish (and, subsequently, the tribal food chain). ${ }^{9}$

In order to circumvent the roads and train routes blocked off by the police to prevent political protests, these women navigate unknown waterways that Great-Great-Grandmother Dora-Rouge (who is traveling to her ancestral lands in order to die) keeps in her cartographic memory. Her oral-memorial maps are accompanied by an assortment of ancient colonial maps collected by Bush, a Chickasaw woman in Dora-Rouge's family. For years Bush has collected old maps that record these ancestral water roads albeit superficially. She herself understands that the two-dimensional surface of maps is unable to reflect the dynamism of the boundary waters region, which is in a perpetual state of transformation (SS

\footnotetext{
9 The flooding also resulted in the drowning of hundreds of deer and caribou. See Warner's chapter in Hornig 1999, and also the written and audiovisual documents compiled by the CBC Archives: http://archives.cbc.ca/society/native_issues/topics/ 94. Phase II of the complex, the Great Whale Project, which would have included the construction of 27 dams, 374 dikes and nine power stations in the mid-1990s was stopped thanks to protests similar to those depicted in the novel (Melmer 1994). For a detailed analysis of these events in relation to Hogan's novel see also Tarter (2000).
} 
123). And yet she collects these maps in order to know how these waterscapes are perceived and used by dominant Western society, taking whatever useful knowledge may be obtained from this dominant geo-historical perspective. The Native roots of many of these colonial maps should also be noted, for most early maps in America were based on oral and visual information that was delivered to European explorers by Native informants. ${ }^{10}$ Bush is, therefore, an example of a self-taught Indigenous geographer that is open to and can strategically appropriate other cultures' historical experiences and interpretations of water and territory. She understands that taking into account all human and other-thanhuman experiences of the land may be key to the creation of respectful and sustainable environments and the study of these colonial maps as a kind of palimpsest may render some information useful to their endeavors. Still, when the four women lose their way in the intricate maze of northern waterways no longer depicted in Bush's maps, Dora-Rouge's blood memory and stories, knowledge of the land, and their dream maps, based on ancestral Indigenous practices in the area, will provide a compass towards survival (Flys 253).

Hogan's literary waterscape explores and anticipates three key ideas that resonate in recent geographical studies of water environments and that have also been engaged by many ecocritics: First, Solar Storms offers a reconfiguration of water geographies that aims to decolonize border history while inscribing Indigenous knowledge and experience. According to geographer Amita Baviskar, water is a natural "boundary-blurring agent" (qtd in Amitangshu 373), and Hogan's literary landscape certainly aims to use this boundary-breaking potential as a site of contestation to criticize colonial dominance while restoring transborder Indigenous networks that are centuries old. ${ }^{11}$ Hogan reminds us that tribal cultures are not static entities but communities that have always engaged processes of change-organic transformations that, like the land and

\footnotetext{
10 Western maps in Bush's collection were drawn between 1660 and 1720. On Indigenous map-making practices, see Mark Warhus' Another America: Native American Maps and the History of Our Land.

${ }^{11}$ Ecocritical and spatial analyses of the novel that have persuasively and more thoroughly unpacked such "defiant cartographies" (Stacks 161) are Tarter (2000), Arnold (2004), Johnson (2007), and Stacks (2010).
} 
in connection with the land, challenge European conceptions of the boundary. In the novel, the physically and psychologically scarred teenage protagonist Angel Jensen often reflects on the superficiality and inaccuracies of European maps. The land had a will of its own and "refused to be shaped by the makers of maps" (SS 123). Adam's Rib, which is surrounded by water is, in fact, described in the novel as a catalyst of both containment and liberation, a "place where water was broken apart by land, land split open by water so that the maps showed places both bound and, if you knew the way in, boundless" (SS 21).

Throughout the novel, activist and geographer Bush, Angel's timid and withdrawn surrogate grandmother, will also reconstruct her interior landscape. For years, she had been living in a small island by Adam's Rib in self-exile, after having been abandoned by her husband, her adopted daughter Hannah and, ultimately, having been deprived of Angel's company when she was violently taken away by government agents. Mishuana Goeman reminds us that the "[c]olonial spatializing of [Native] lands, bodies, and minds has occurred since contact: maps, travel logs, engravings, newspapers, almanacs, and many other forms of colonial writings formed a systematic practice of confining and defining Native spaces from land to bodies" (296). But how can a static map, which is essentially a snapshot, hope to capture something as inherently dynamic as water and the environment containing it? In her journey north, Bush learns to reverse this spatializing and confining power of colonial maps, the very maps she collected and studied, and "open[s] like the lilies that flowered on some of the islands It was as if she had needed this place and all this water [...] She was as uncontained as she had previously been contained by skin, house, island, and water. Now it seemed there were no borders" (176). ${ }^{12}$ In Solar Storms, experiential approaches to the land overtake maps as a dynamic and more meaningful source of spatial knowledge-one that is based on memorial histories, relationality and "placed-based solidarity" (Coulthard 2016). As Angel points out towards the end of the novel: "There is no map to show where to step, no guide to tell us how to see" (SS 346).

\footnotetext{
${ }^{12}$ On the impossibility of European maps to comprehend the ecologic dynamism of the boundary waters region, see also Kelli Lyon Johnson's “Writing Deeper Maps” (2007).
} 
A second key aspect highlighted in Hogan's novel is the fact that, within waterscapes, water "connects many realms of social life" (Orlove and Caton 401) and may function as an agent of political transformation and empowerment for a variety of social actors that have been historically disenfranchised. As water archeologist Zena Kamash points out, "the transmutability of water shapes discourse" (225). In this respect, it is essential to highlight that many Native American and Indigenous environmental justice leaders such as Winona LaDuke or the late Berta Cáceres are women who brought public attention to water rights and environmental sustainability, and this was most recently seen in the \#noDAPL movement, where female leadership has been outstanding (Brígido-Corachán 2017). In a similar manner, Solar Storms renders a polyphony of transformative journeys through the Boundary Waters for each one of its leading women. The trip becomes a political awakening for Bush who, as we have seen, finally takes direct action and joins environmental protestors against the dam after years of isolation in her island. The journey is also a dying pilgrimage for Angel's greatgreat-grandmother Dora-Rouge, who wants to rest in her homeland, north of a border that continues to divide her people. It is also a memorial journey for Agnes, who expects to bury her mother at their destination. Last, and most importantly, it is a voyage of selfdiscovery for Angel, who is also traveling to Two-Town to face her mother, Hannah Wing, who tortured and abandoned her when she was a child. These four women ply their existential, memorial, cultural, and political projects to fluid spatial movements that, following the water landscape converge, cross-feed, and intertwine. For all of them, the canoe-voyage through these waterlands will also be a rite of passage, an inward, healing journey, a path to come fullcircle with themselves. ${ }^{13}$

But Solar Storms most keenly focuses on Angel's psychological ordeal to come to terms with her stolen tribal identity, as she spent most of her life in inhospitable foster homes in Oklahoma and had just recently been reunited with her grandmothers at Adam's Rib. Through the novel Angel moves from environments of violence, pain, and trauma to those of family,

\footnotetext{
13 Canoe journeys of initiation as a cultural rite of passage are also common in Annishnaabe culture. See Cook (2003) and Arnold (2004) for further details on this cultural practice.
} 
heritage, nature, care, and healing. Angel's scarred body thus functions in many ways as a site of memory in the novel-a repository of the psychological trauma undergone by many stolen Native children throughout the $20^{\text {th }}$ century. Her relocation to a foster home, at a very early age, fractured the memorial and affective networks that connected her to her family, networks that she will have to reconstruct upon returning. In the canoe, moving north through the myriad water channels, as she recuperates the traditional environmental knowledge and practices of her people using it to care for others, Angel partially exorcises the painful histories of many such children who were brutally removed from their families, following the genocidal, acculturating policies of the nation.

For teenage narrator Angel, water thus functions as a catalyst and a cure, as she had already begun to heal while spending the winter with Bush on Fur Island-a bare piece of wilderness symbolically surrounded by water. When Angel's smudged mirror breaks, interrupting her obsession with her facial scars, Angel instead gains vision; she is finally able to see "inside water," "see to the bottom of things" that lie under the surface (SS 85-6). Water becomes a window into other natural worlds, a threshold or portal that will connect her to other-than-human persons like plants and fish. ${ }^{14}$ The sighting of fish on the isolated island restores to her the ancestral will to survive. It is, for example, while diving in the water during the canoe journey to Canada, where Angel discovers the Indigenous petroglyphs preserved on the rocks that mark the ancient ways through the Boundary Waters and serve as a carved reminder of the historical Native presence in those fluid environments (Arnold 290).

As for me, I was awake in time that was measured from before axes, before traps, flint, and carpenter's nails. It was this gap in time we entered, and it was a place between worlds [...] Everything merged and united [...] Water and air became the same thing, as did water and land in the marshy broth of

\footnotetext{
${ }^{14}$ Breaking the mirror is a classic trope of female rebellion that challenges patriarchal constructions of womanhood based on beauty and submissiveness (see Gilbert and Gubar 1984). The shattering of what was an already smudged mirror encourages Angel to embrace a more empowered and independent idea of womanhood that takes into account her Native heritage.
} 
creation. Inside the clear water we passed over, rocks looked only a few inches away. Birds swam across lakes. It was all one thing. The canoes were our bodies, our skins. We passed through green leaves, wild rice, and rushes. In small lakes, dense with lily pads, tiny frogs leaped from leaves into the water as we passed (SS 177)

Native bodies themselves are seen as vessels for water memories. Dora-Rouge's old body is in fact described as a waterscape: "her hands knotted with veins and human tributaries, intricacies..." (SS 31). Water, in its rain cycle, is also compared to the blood of her ancestors as "it had journeyed through human lives. It was blood spilled on the ground" (SS 78). Finally, with its cyclic movement, water also functions like time itself, as a transforming agent that puts different histories and experiences in contact with one another. It thus evokes recent geographical studies of waterscapes which describe them as multivocal and "experientially meaningful" (Orlove and Caton 408) while emphasizing its overlapping, silenced histories. In the novel, these interconnected, silenced histories will be unveiled to signal resurgence and transformation as Indigenous values that are engrained in the landscape itself.

The third idea explored in Hogan's waterscape is precisely this very connection: the communicative interactions that are established between humans and other-than-human beings whose own marginalized practices and silenced historical experiences must be acknowledged and respected. Trees can "hear" and the land has "eyes" that observe Angel's movements (SS 188). Most importantly, water in her many shapes proves to have an agency and will of her own that is grounded on her own historical experience: rivers fight because they "had probably never liked each other" (SS 195), the lake is "alive" and "so [is] the ice itself" (SS 129). Water also establishes continuous relations with human and other-than-human persons. When Angel dives to see the paintings (petroglyphs of fish and deer) on the river walls, she remembers being fish, "being oxygen and hydrogen, bird and wolverine [...] [and] understood how these simple elements married and became a third thing" (SS 179). ${ }^{15}$ In Hogan's

${ }^{15}$ It is also when the rock becomes wet that the paintings of wolverine on the rocks
show that he has wings (SS 177), and this is symbolic because, at the end of her 
waterscape all creatures, human and other-than human persons, are interrelated, live in respectful coexistence, have "communicative potential" (Flys 245), and engage each other in meaningful and caring ways.

Dialogical interspecies ethics has become prominent in many contemporary philosophical, ecocritical, and environmentalists studies written by non-Indigenous scholars although many of these studies have most frequently focused on animals, rather than water, soil or plants. ${ }^{16}$ In contrast, these issues are still barely emerging in the field of political geography and, when they do, it is within an Indigenous or Postcolonial framework. In that respect, Hogan's depiction of a multivocal waterscape where water is portrayed as a central agent was certainly pioneering. In the novel, such interspecies dialogue is most compellingly rendered through DoraRouge's conversation with water. The journey through the waterways triggers a linguistic awakening in Dora-Rouge, who is able to retrieve the language of water out of her deep memory, in a moment of utter danger. She speaks to the Se Nay River and asks the unruly, overflooded water for passage. The river will grant her this wish but within a context of reciprocality that will require a sacrifice. DoraRouge believes she has offered her own life in return, but the river takes that of her daughter Agnes instead. In this passage, water manifests having a will of her own, for her interpretation of the pact is slightly different from Dora-Rouge's; there is a certain linguistic misunderstanding, or perhaps the river chooses to honor the pact by taking a body that will better suit the waterscape. Agnes's body, surrounded by life-giving flowers, is left floating in the water to be eaten by birds and wolverines (following Agnes' own wish). This action respects and embraces the ceremonial circularity and reciprocality of the relation established with the river. Agnes's last stance thus enacts a radical form of relationality with nature, as her

journey, Angel will reclaim her last name: Wing. She manages to strengthen her roots while remaining boundless.

16 See for example Plumwood's groundbreaking Environmental Culture (2002), Warkentin (2010) or, most recently, Willett (2014). Classic studies on interspecies ethics that take into account other-than-human persons that are not animals are for example Plumwood's and, most recently, Indigenous place-based ethics based on relationality and responsibility such as McGregor's (2013) and Coulthard's (2014). 
own self ends up blending with the waterscapes' other-than-human inhabitants. ${ }^{17}$

In the last section of the novel Hogan explores the negative consequences of waterscapes when these are seized and exploited by human communities to suit their needs. Indeed when the party of women finally reaches Two-Town and the threatening dam, they find a decimated Inuit community who has been displaced and who is now living in the outskirts of the construction. It is a devastated, dystopian-like ecosystem and the dam has become another means through which dominant society exploits and manages the lives of human and other-than human collectives.

In stark contrast with this bleak reality, Hogan has been giving us the key to the creation of a respectful, sustainable environment: human individuals and societies have to "recognize empathetic connections between landscapes and humans" (Castor 174), they must take into account and communicate with natural forces and other-than-human persons as we are all interdependent. ${ }^{18}$ According to Jim Tarter, Solar Storms also vindicates "a common animality, a common plant nature, a common earthliness" (145). Throughout her novel, Hogan has argued that if we are to engage these water environments, it has to be in a sustainable, responsible, and reciprocal manner-one that attends to and respects all of its inhabitants. Drawing from her own traditional environmental knowledge and considering other-than-human practices and experiences in the waterscape Bush suggests that people should follow the creative model of beavers:

Beavers were the true makers of the land. It was through their dams that the geographies had been laid, meadows created, through their creation that young trees grew, that deer came, and moose. All things had once depended on them. And on these maps, we could read back to how land told the story of the beaver people (SS 123)

\footnotetext{
${ }_{17}$ Another character who listens to the water and can understand and respect its will is Auntie, a Native kin of the four protagonists of the story who lives at the protest site, Two-Town. Auntie uses her medicine bundle to help water go "back to where water wanted and needed to be" (277).

18 On the notion of interdependence in Native American environmental philosophies and ceremonies see also the work of Navajo philosopher Gregory Cajete (2000).
} 
According to one of the Native elders in Two Town, Tulik, beavers created the world "when the world was still covered by water", they also "shaped the humans, who were strangers to the rest of creation, they made a pact with them [...] [t]hey would help each other. Beaver offered fish and waterfowl and animals. The people, in turn, would take care of the world" (SS 238-9). This ancestral environmental knowledge, articulated through the principles of interdependence, respect, and care, will be reaffirmed by Angel, the story's narrator and a member of the younger generation of Indigenous protectors. ${ }^{19}$ Although the rivers will drown and all lands and creatures around them will eventually be flooded by the dam, Angel's new ability to listen to the land, to call animals using Dora-Rouge's old song, her vision to share this story with others, will be ultimately highlighted over disaster. At the end of the novel Angel can hear Agnes's distant voice "say[ing] that a human is alive water, that creation is not yet over" (SS 350). She recognizes the power of creation in the world and inside each one of us, a valuable lesson that she has learned while being inside water.

\section{CONCLUSION}

Four years after the publication of Solar Storms, waterscape studies started to take into account the very same issues (sustainability, cultural interpretation, spirituality, social inequality, and justice) that Hogan had explored in her novel. Today, many political geographers agree that power and social relations have to be renegotiated in the waterscapes (and this includes interactions between humans and nature). They also recognize that water is not just a material commodity that is subservient to human ends. As Acharya points out: "(W)ater interacts with the non-human as well as the human" and, therefore, "non-human entities", geological layers, and materials should also be considered if these environments are to be truly sustainable (376). Finally, these studies also suggest that control over water cannot be seen as a "cultural conquest" (Acharya 378). Any contemporary study of waterscapes must take into account

\footnotetext{
${ }^{19}$ For a parallel reading of this passage in relation to the novels' defiant maps see also Stacks (2010).
} 
the variety of cultural beliefs, religions, forms of spirituality, social practices, identities, needs, experiences and imaginations that interact within these sites.

As we have seen, Linda Hogan's waterscape is conceived as a place that attests to many layers of human and other-than-human meaning and experience. It describes the swirling action of water, a potentially unstoppable force that can be both destructive and creative, and which, in the novel, becomes a form of environmental/spiritual power. Water is power, hydroelectric and economic, but it is also imbued with Native spirituality, history and culture. Water is a life-giving force and has restorative properties for individual and communal bodies. In the novel waterscapes function as an arena of cultural and political transformation for Native communities and activists like Bush and Auntie, who learn to navigate and play a role as key agents in an ocean of geopolitical changes, while remaining firmly anchored to tradition and to the convoluted and changing history of the region.

At one point in the novel Angel points out that "it is not that the ways are lost from us but that we are lost from them. But the ways are patient and await our return" (SS 346). Thus, water functions as a transmutable entity and key trope to describe the potential swirling action of the new social movements of Native resistance that re-emerged in the early 1970s and which are gaining more and more visibility in the $21^{\text {st }}$ century. Such a swirling action is today reconnecting Native youths with their own heritage and with the traditional environmental knowledge of their ancestors, as we have recently seen with the \#noDAPL movement. Thus, water is effectively contributing to the building of intertribal, intergenerational political networks that can negotiate openings; it is triggering visible changes in the environmental practices of the Americas.

\section{WORKS CITED}

ACHARYA, Amitangshu, "27. The Cultural Politics of Waterscapes," International Handbook of Political Ecology, Ed. Raymond L. Bryant. Edward Elgar Pub, 2015, pp. 373.

ARNOLD, Ellen J. "Beginnings are Everything. The Quest for Origins in Linda Hogan's Solar Storms,"Things of the Spirit. Women Writers Constructing Spirituality, edited by K. Groover, University of Notre Dame Press, 2004. 
BARRETT, Mary Jeanne. Beyond Human Nature Spirit Boundaries. Researching with Animate Earth. University of Regina, 2009. www.porosity.ca/pages/Executive_Summary.pdf

BAUER, William J. Jr. California through Native Eyes: Reclaiming History. Seattle and London: University of Washington Press, 2016.

BAVISKAR, Amita. "For a Cultural Politics of Natural Resources". Economic and Political Weekly, vol. 38, n. 48, Nov. 29 - Dec. 5, 2003, pp. 50515055 .

BBC News. "New Zealand river first in the world to be given human legal status" BBC World. 15 March 2017. www.bbc.com/news/world-asia39282918. Accessed 17 March 2017.

BRÍGIDO-CORACHÁN, Anna M. "Material Nature, Visual Sovereignty, and Water Rights: Unpacking the Standing Rock Movement". Studies in the Literary Imagination. Special Issue: $2^{\text {st }}$ Century American Crises: Reflections, Representations, Transformations: Part 1, edited by Ana Fernández-Caparrós, Vol. 50, n. 1, Spring 2017.

CAJETE, Gregory. Native Science: Natural Laws of Interdependence. Santa Fe: Clear Light, 2000.

CASTOR, Laura Virginia. "Claiming Place in Wor(l)ds: Linda Hogan's Solar Storms. MELUS, vol. 31, n. 2, Summer 2006, pp. 157-180.

CBC Archives. CBC Radio-Canada. archives.cbc.ca/society/native_ issues/topics/94. Accessed March 2009.

COOK, Barbara J. "Hogan's Historical Narrative. Bringing to Visibility the Interrelationship of Humanity and the Natural World". From the Center of Tradition: Critical Perspectives on Linda Hogan, edited by B. J. Cook. Boulder: University Press of Colorado, 2003, pp. 35-52.

COULTHARD, Glen, Red and White Masks. Rejecting the Colonial Politics of Recognition. University of Minnesota Press, 2014.

COULTHARD, Glean and Leanne Betasamousake Simposon. "Grounded Normativity/Place-Based Solidarity”. American Quarterly, vol. 68, n. 2, 2016, pp. 249-255.

DREESE, Donelle, "The Terrestrial and Aquatic Intelligence of Linda Hogan" Studies in American Indian Literatures vol. 11, n. 4, Winter 1999, pp. 6-22. 
FLYS JUNQUERA, Carmen. “(Un)Mapping (Ir)rational Geographies: Linda Hogan's Communicative Places". The Future of Ecocriticism: New Horizons, edited by Serpil Oppermann et. al. Cambridge Scholars Publishing, 2011.

GOEMAN, Mishuana R. "(Re)Mapping Indigenous Presence on the Land in Native Women's Literature" American Quarterly, vol. 60, n. 2, 2008, pp. 295-302.

HALLOWELL, A. Irving. "Ojibwa Ontology, Behavior, and World View." Culture in History: Essays in Honor of Paul Radin, edited by S. Diamond, Columbia University Press, 1960, pp. 19-52.

HANS, Birgit. "Water and Ice: Restoring Balance to the World in Linda Hogan's Solar Storms" North Dakota Quarterly Summer 2003, vol. 70, n. 3, pp. 93-104.

HORNIG, James F, ed. Social and Environmental Impacts of the James Bay Hydroelectric Project. Montreal: McGill-Queen University Press, 1999.

JOHNSON, Kelli Lyon. "Writing Deeper Maps." Studies in American Indian Literatures, vol. 19, n. 4, Winter 2007, pp. 103-120.

JOHNSTON, Basil. Ojibway Heritage: The Ceremonies, Rituals, Songs, Dances, Prayers and Legends of the Ojibway. Toronto: McCLelland and Stewart, 1976.

KAMASH, Zena. "What Lies Beneath? Perceptions of the Ontological Paradox of Water." World Archeology, vol. 40, n. 2, 2008, 224-237.

MCGREGOR, Deborah. "Anishinaabe Environmental Knowledge". Contemporary Studies in Environmental and Indigenous Pedagogies: A Curricula of Stories and Place, edited by A. Kulnieks, D.R. Longboat and K. Young, Sense Publishers, 2013, pp. 77-88.

MELMER, David. "Canadian native groups score victory over massive Hydro Quebec.” Indian Country Today. 7 December 1994.

ORLOVE, Ben and Steven C. CATON "Water Sustainability: Anthropological Approaches and Prospects”. Annual Review of Anthropology vol. 39, 2010, pp. 401-415. JSTOR. Accessed June 28th 2016.

PLUMWOOD, Val. Environmental Culture. The Ecological Crisis of Reason. Routledge, 2002. 
REYNOLDS, GLENN. "A Native American Water Ethic" Transactions, vol. 90, 2003, pp.143-161,http://calwater.ca.gov/content/documents/libra ry/tribal/native_american_water_ethic_reynolds.pdf.

SAFI, Michael. "Ganges and Yamuna rivers granted same legal rights as human beings" The Guardian. 21 March 2017. https:/ / www.theguardian.com/world/2017/mar/21/ganges-andyamuna-rivers-granted-same-legal-rights-as-human-beings.

Accessed 21 March 2017.

SCHWENINGER, Lee. Listening to the Land: Native American Literary Responses to the Landscape. University of Georgia Press, 2010.

SILKO, Leslie. Sacred Water. Flood Plain Press, 1991.

SMITH, Lindsey Claire and Trever Lee HOLLAND. "Beyond All Age': Indigenous Water Rights in Linda Hogan's Fiction." Studies in American Indian Literatures, vol. 28, n. 2, Summer 2016, pp. 56-79.

STACKS, Geoffrey. "A Defiant Cartography: Linda Hogan's Solar Storms". Mosaic, vol. 43, n. 1, March 2010, pp. 161-176)

SWYNGEDOUW, Erik. "Modernity and Hybridity: Nature, Regeneracionismo, and the Production of the Spanish Waterscape, 1890-1930." Annals of the Association of American Geographers, vol. 89, n. 3, 1999, pp. 443-465.

TARTER, Jim. “'Dreams of Earth': Place, Mutiethnicity, and Environmental Justice in Linda Hogan's Solar Storms." Reading Under the Sign of Nature: New Essays on Eco Criticism, edited by J. Tallmadge and H. Harrington, Salt Lake City: University of Utah, 2000.

TRAFZER, Clifford. "Pulsating Webs of Puha and Healing". Indigenous Environments. Native Studies Research Network UK. University of East Anglia, July 2016. Conference paper.

WARHUS, Mark. Another America: Native American Maps and the History of Our Land. New York: St. Martin's Press, 1997.

WARKENTIN, Traci. "Interspecies Etiquette: An Ethics of Paying Attention to Animals." Ethics \& the Environment, vol. 15, n.1, 2010, pp. 101-121.

WILLETT, Cynthia. Interspecies Ethics. Columbia University Press, 2014. 